\title{
Song Discrimination by Male Mourning Warblers (Geothlypis philadelphia) and Implications for Population Divergence across the Breeding Range
}

\author{
JAY PITOCCHELLI
}

Biology Department, Saint Anselm College, Manchester, New Hampshire 03102 USA; email: jpitocch@anselm.edu

Pitocchelli, Jay. 2014. Song discrimination by male Mourning Warblers (Geothlypis philadelphia) and implications for population divergence across the breeding range. Canadian Field-Naturalist 128(4): 408-415.

Geographic variation in song may reduce or eliminate the ability of some populations to recognize each other as conspecifics, possibly leading to assortative mating, reproductive isolation, and speciation. Song playback experiments, used to evaluate the significance of geographic variation in song, have been particularly useful in discovering divergence among previously unknown populations of sibling species. In this study, I report the results of song playback to male Mourning Warblers (Geothlypis philadelphia) from populations throughout the breeding range and discuss the implications for population divergence. Four regions in the breeding range contain unique song types or regiolects: western, eastern, Nova Scotia, and Newfoundland. Results of reciprocal song playback experiments showed that males from the western and Newfoundland regiolects respond more aggressively to songs in their own regiolect than those in the other regiolects. Interior populations, i.e., eastern and Nova Scotia regions, showed little or no difference in aggressive response toward their own versus other regiolects. This pattern may be due to a combination of geographic proximity of populations belonging to different regiolects, song learning, experience, and contact during migration. Song discrimination by populations from the western Prairie Provinces and Newfoundland is consistent with the existence of at least partial reproductive isolation at the geographic extremes of the breeding range.

Key Words: Mourning Warbler; Geothlypis philadelphia; song; playback experiment; song discrimination

\section{Introduction}

Birdsong is a reproductive display recognized by a network of males and females of the same species (Paterson 1985; McGregor and Dabelsteen 1996). It is regarded as one of the most compelling examples of a prezygotic isolating mechanism (Remsen 2005; Hall and Hallgrimsson 2008). Because birdsong plays such an important role in maintaining reproductive cohesion among populations of the same species, instances of gradual divergence, such as geographic variation, may challenge the ability of birds to recognize songs from different parts of the breeding range leading to reproductive isolation and speciation (Edwards et al. 2005; Price 2008). Geographic variation in oscine songbirds is well known and has been described at two spatial scales (see reviews of Mundinger 1982; Podos and Warren 2007). Song differences between contiguous populations separated by short distances and capable of interbreeding is referred to as microgeographic or dialect variation. Macrogeographic or regiolect variation occurs where large regions of the breeding range contain unique song types.

In an article on the role that song variation plays in species-level classification, Remsen (2005) asked how much variation in song is required to exceed the limits of species recognition, create barriers to gene flow, and result in speciation. Studies of geographic variation in song coupled with playback experiments present an opportunity to address this issue. Playback experiments with territorial males have been used to test hypotheses about song discrimination in many species at the dialect and regiolect levels (Baker et al. 1981; Searcy et al.
1997; Price 2008). Similarly, song playback experiments have been performed on captive females, implanted with estradiol, to test female discrimination of song types from different parts of the breeding range (Balaban 1988; Searcy 1992; Searcy et al. 2002; Anderson 2009; Danner et al. 2011).

A general result of playback studies at the dialect and regiolect levels is evidence that members of both sexes are capable of song discrimination. Males react more aggressively to homotypic or local songs shared with their neighbours compared with foreign or heterotypic songs from different parts of the breeding range. Females respond more favourably to homotypic songs (Price 2008). Research on the effects of song variation and discrimination on gene flow has been mixed. Studies at the microgeographic level have shown that dialects do not act as barriers to gene flow in the Yellow-naped Parrot (Amazona auropalliata; Wright and Wilkinson 2001), the White-crowned Sparrow (Zonotrichia leucophrys; Soha et al. 2004), and the Brown-headed Cowbird (Molothrus ater; Fleischer and Rothstein 1988). However, genetic and morphologic divergence have been correlated with song differences among subspecies of the Swamp Sparrow (Melospiza georgiana; Liu et al. 2008) and regiolects in several Palearctic species belonging to the genera Parus and Phylloscopus (Helbig et al. 1996; Martens 1996; Irwin et al. 2001).

In this paper, I report the results of song playback experiments with territorial male Mourning Warblers (Geothlypis philadelphia). This species is monotypic, with a large breeding range extending over much of 
Canada and parts of the eastern United States (Mayr and Short 1970; Pitocchelli 2011a). There is a welldefined pattern of geographic variation in songs, with four regiolects: western, eastern, Nova Scotia, and Newfoundland. Songs of males within each regiolect are very similar; variation within a regiolect is usually minor and involves the omission or substitution of a single syllable. A zone of admixture exists in western Ontario, Minnesota, and Wisconsin where males from both the western and eastern regiolects breed. Hybrid songs containing a mix of western and eastern syllable types have been recorded in this zone (Pitocchelli 2011b). Although geographic variation in song exists, it is unknown to what degree these song differences are recognized by populations of each regiolect.

I conducted a series of reciprocal playback experiments within the geographic boundaries of each regiolect to test three hypotheses. First, populations within each regiolect discriminate between songs from all of the other regiolects. The prediction from this hypothesis is that the responses of males will be more aggressive toward playback of homotypic songs from the same regiolect versus heterotypic songs of each of the other regiolects. Second, populations within each regiolect are partly capable of song discrimination. The prediction here is that there will be higher levels of aggression by males to homotypic songs versus heterotypic songs of some but not all of the other regiolects. Third, populations within each regiolect do not discriminate between homotypic songs and heterotypic songs of any of the regiolects. The prediction from this hypothesis is that males within each regiolect show equal levels of aggression toward homotypic and heterotypic songs. The results of this study show that response differences and song discrimination do occur, but are not consistent throughout the breeding range. I discuss the effect of geographic proximity on the pattern of song discrimination and the implications of song discrimination for reproductive isolation among breeding populations.

\section{Study Area}

I selected study sites for playback experiments within the geographic boundaries defining each regiolect: western, eastern, Nova Scotia, and Newfoundland (Figure 1). Latitude and longitude of study sites were Hudson Bay, Saskatchewan, $53.96^{\circ} \mathrm{N}, 102.35^{\circ} \mathrm{W}$; Duck Mountain Provincial Park, Manitoba, $51.89^{\circ} \mathrm{N}$, $100.85^{\circ} \mathrm{W}$; Marathon, Ontario, $48.68^{\circ} \mathrm{N}, 86.10^{\circ} \mathrm{W}$; Twin Mountain, New Hampshire, $44.20^{\circ} \mathrm{N}, 71.70^{\circ} \mathrm{W}$; Oxbow, Maine, $46.33^{\circ} \mathrm{N}, 68.42^{\circ} \mathrm{W}$; Wreck Cove, Nova Scotia, $46.08^{\circ} \mathrm{N}, 60.80^{\circ} \mathrm{W}$; and Stephenville Crossing, Newfoundland, $48.60^{\circ} \mathrm{N}, 58.35^{\circ} \mathrm{W}$.

\section{Methods}

Approximately 30 focal males from each regiolect were evenly divided into three experimental groups (Table 1). Group I was presented with homotypic songs from their own regiolect and heterotypic songs from one of the foreign regiolects (e.g., western focal males presented with western versus eastern songs). Group II

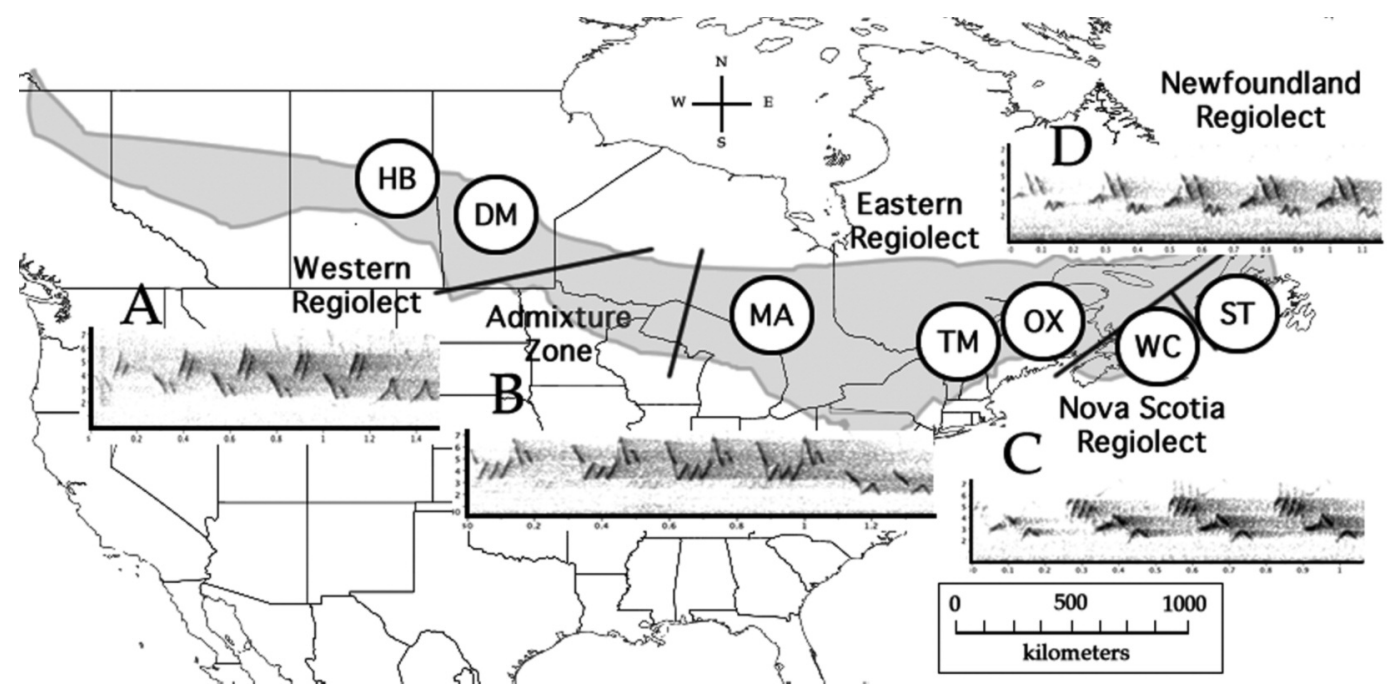

FIGURE 1. Distribution of the four regiolects of the Mourning Warbler (Geothlypis philadelphia), locations of the playback experiments, and sample songs from: A, the western regiolect; B, the eastern regiolect; $\mathrm{C}$, the Nova Scotia regiolect; and D, the Newfoundland regiolect. Western study sites were Hudson Bay, Saskatchewan (HB) and Duck Mountain Provincial Park, Manitoba (DM); eastern study sites were Marathon, Ontario (MA), Twin Mountain, New Hampshire (TM), and Oxbow, Maine (OX); the Nova Scotia study site was Wreck Cove (WC), and the Newfoundland study site was Stephenville Crossing (ST). Shaded region indicates distribution of breeding range. 
TABLE 1. Design and number of playback experiments to test song discrimination by Mourning Warblers (Geothlypis philadelphia) throughout their breeding range.

\begin{tabular}{|c|c|c|c|c|}
\hline $\begin{array}{l}\text { Playback } \\
\text { locality }\end{array}$ & $\begin{array}{l}\text { Focal } \\
\text { male's } \\
\text { song* }\end{array}$ & Regiolect of playback songs $(n)$ & $\begin{array}{l}\text { Mean difference } \\
\text { in Principal } \\
\text { Component } 1 \\
\text { Scores }(95 \% \mathrm{CI})\end{array}$ & $\begin{array}{c}\text { Level of } \\
\text { significance } \\
\text { Student's } t \text { test } \dagger\end{array}$ \\
\hline $\begin{array}{l}\text { Western regiolect (WR): } \\
\text { Hudson Bay, } \\
\text { Saskatchewan; Duck } \\
\text { Mountain Provincial } \\
\text { Park, Manitoba }\end{array}$ & WR & $\begin{array}{l}\text { Group I: WR vs. ER (9) } \\
\text { Group II: WR vs. NSR (10) } \\
\text { Group III: WR vs. NFR (10) }\end{array}$ & $\begin{array}{l}0.46(0.39) \\
1.72(0.67) \\
0.99(0.58)\end{array}$ & $\begin{array}{l}P=0.026 t \\
P<0.001 \\
P=0.004\end{array}$ \\
\hline $\begin{array}{l}\text { Eastern regiolect (ER): } \\
\text { Marathon, Ontario; Twin } \\
\text { Mountain, New Hampshire; } \\
\text { Oxbow, Maine }\end{array}$ & ER & $\begin{array}{l}\text { Group I: ER vs. WR (11) } \\
\text { Group II: ER vs. NSR (10) } \\
\text { Group III: ER vs. NFR (9) }\end{array}$ & $\begin{array}{l}0.38(0.67) \\
1.16(0.68) \\
0.99(1.16)\end{array}$ & $\begin{array}{l}P=0.238 \S \\
P=0.004 \\
P=0.085 \S\end{array}$ \\
\hline $\begin{array}{l}\text { Nova Scotia regiolect } \\
\text { (NSR): Wreck Cove }\end{array}$ & NSR & $\begin{array}{l}\text { Group I: NSR vs. WR (10) } \\
\text { Group II: NSR vs. ER (12) } \\
\text { Group III: NSR vs. NFR (10) }\end{array}$ & $\begin{array}{c}0.00(1.18) \\
0.48(0.58) \\
-0.04(0.79)\end{array}$ & $\begin{array}{l}P=0.997 \S \\
P=0.095 \S \\
P=0.913 \S\end{array}$ \\
\hline $\begin{array}{l}\text { Newfoundland regiolect } \\
\text { (NFR): Stephenville } \\
\text { Crossing }\end{array}$ & NFR & $\begin{array}{l}\text { Group I: NFR vs. WR (10) } \\
\text { Group II: NFR vs. ER (10) } \\
\text { Group III: NFR vs. NSR (10) }\end{array}$ & $\begin{array}{l}1.67(0.64) \\
1.08(0.62) \\
1.27(1.06)\end{array}$ & $\begin{array}{l}P<0.001 \\
P=0.003 \\
P=0.024 \ddagger\end{array}$ \\
\hline
\end{tabular}

Note: $\mathrm{CI}=$ confidence interval.

*Confirmed by digital recordings.

$\dagger$ Two-tailed comparison; null hypothesis is that the mean difference is equal to zero.

$\ddagger$ Not significant after sequential Bonferroni correction.

$\S$ Not significant.

was challenged with homotypic songs and heterotypic songs from a different regiolect (e.g., western focal males presented with western versus Nova Scotia songs). Group III was challenged with homotypic songs and heterotypic songs from the remaining regiolect (e.g., western focal males presented with western versus Newfoundland songs). To ensure that multiple stimuli represented a class of stimuli and to minimize pseudoreplication (Kroodsma 1989; Kroodsma et al. 2001), each focal male was presented with a unique combination of different, randomly selected homotypic and heterotypic songs. I selected 30 western, 30 eastern, 30 Nova Scotia, and 30 Newfoundland exemplar songs for this study. Each song was from a different male. I made the selections based on the best recordings from earlier work on this species (Pitocchelli 1988, 1990, 2011b).

I used the simultaneous, two-speaker presentation of auditory stimuli model for playback experiments (Lanyon 1978). Simultaneous presentation of different song types tests the comparative prioritization of responses and reveals which song is perceived to be a greater threat to a territorial male (Darren Irwin, Biodiversity Research Centre and Department of Zoology, University of British Columbia, 7 April 2014, personal communication). I placed two PureFi Anywhere speakers (Logitech, Lausanne, Switzerland) approximately $30 \mathrm{~m}$ apart (positions 1 and 2), on either side of the first song post that I observed for each male. I assumed that this song post was within the territory of the focal male.
The speakers were each connected to an iPod (Apple Inc., Cupertino, California, USA). For the first four minutes of the experiment (Period I), regiolect A was played at position 1 while regiolect $B$ was played at position 2 (A and B representing any randomly selected pair of homotypic and heterotypic songs; Figure 2). After two minutes of silence, I conducted another four minute presentation (Period II) with the same songs but with positions reversed, i.e., regiolect $\mathrm{B}$ was played at position 1 while regiolect $A$ was played at position 2). Approximately 19 homotypic and 19 heterotypic songs were presented during each four-minute period, which simulated the average natural rate of one song per 13 seconds by territorial males.

The songs were digitized and assembled using Raven Pro version 1.4 for Mac OSX (Cornell Lab of Ornithology, Bioacoustics Research Program, Ithaca, New York, USA) and iTunes version 8.2.1 (Apple Inc.). Homotypic and heterotypic songs were arranged so that they did not overlap and males could clearly hear all songs during the experiment. When necessary, I manipulated the songs using the amplify settings in Raven so that they were all similar in amplitude. All experiments were performed from 6 to 11 a.m. in June 2008, 2009, and 2010.

I used four response variables to measure aggressive behaviour of the focal males toward either homotypic or heterotypic songs: 1) number of flights toward and/or over a speaker, 2) number of chip notes directed toward a speaker, 3) number of songs directed toward a speak- 


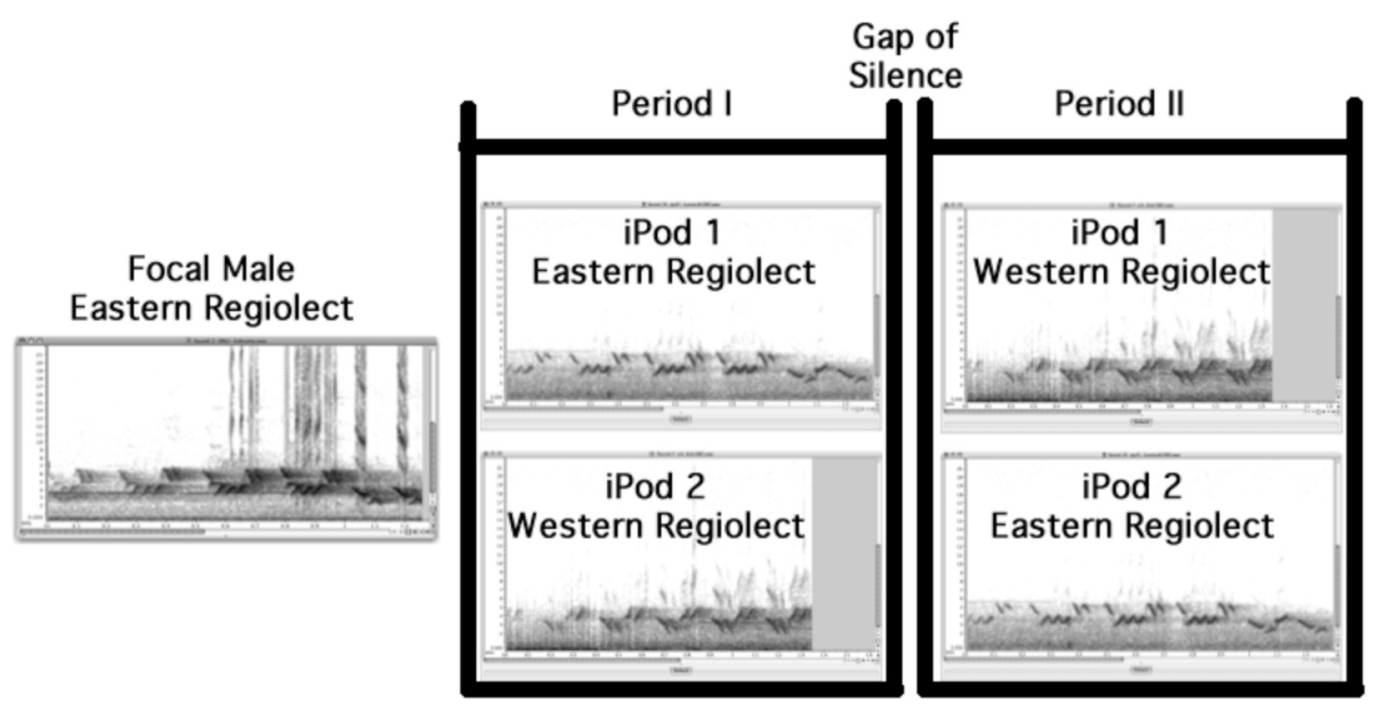

FIGURE 2. Experimental setup for an eastern focal male Mourning Warbler (Geothlypis philadelphia) and his song type challenged by playback of homotypic eastern regiolect and heterotypic western regiolect songs. Periods I and II were four minutes long and separated by two minutes of silence.

er, and 4) time spent within $3 \mathrm{~m}$ of a speaker. For each focal male, the responses to the homotypic song for Period I and Period II were combined, as were the responses to the heterotypic song for Periods I and II.

Before statistical analysis, I transformed the response data following guidelines in Zar (2010) to avoid deviations from normality and to account for the large number of zero data entries often encountered in playback experiments (Balakrishnan and Sorenson 2006). Number of flights, number of chip notes, and number of songs were square root transformed. The time spent within $3 \mathrm{~m}$ of a speaker was $\log _{10}$ transformed, $\log _{10}$ $(x+1)$. I subjected the transformed data to a principal components analysis to reduce the correlated variables to a new set of uncorrelated principal component (PC) scores (Martin and Martin 2001; Balakrishnan and Sorenson 2006). Each male received a PC score based on its combined responses to a homotypic song during Periods I and II. A separate PC score was calculated from the combined responses to the heterotypic song during Periods I and II. I chose scores for the first PC (PC1) for subsequent statistical tests because $\mathrm{PC} 1$ explained $71.4 \%$ of the variation and it was also the best index of aggression. All response variables were positive for PC1: number of flights (0.67), number of chips (0.98), number of songs (0.02), and time spent within $3 \mathrm{~m}$ of the speaker $(0.24)$. Higher PC1 scores indicated higher levels of aggression toward a song type.

I chose a paired samples Student's $t$ test to analyze these data because each focal male was exposed to two treatments: playback of homotypic songs and playback of heterotypic songs. This test determines whether the average difference between PC1 scores for homotypic and heterotypic songs is significantly different from zero for each group in a regiolect. Differences significantly greater than zero indicated a stronger response to the homotypic song, whereas differences significantly less than zero indicated higher levels of aggression toward heterotypic songs. Significant differences in either direction were considered to be evidence of song discrimination. The absence of a significant difference from zero indicated equal levels of aggression toward homotypic and heterotypic songs and was interpreted as an inability to discriminate between these songs.

I performed three paired samples Student's $t$ tests, one for each group (I, II, III) in each regiolect (Table 1). The design produced a total of 12 statistical tests. The differences for PC1 scores did not deviate from a normal distribution for 10 of the 12 statistical tests, which meets a critical assumption of the paired samples Student's $t$ test (Zar 2010). In cases where multiple statistical tests are used, Rice (1989) recommended using a sequential Bonferroni adjustment to correct for possible inflation of probability levels. I began the sequential Bonferroni application with an alpha level indicating a significant difference at $P \leq 0.0042(P=$ $0.05 / 12$ Student's $t$ tests). The use of this adjustment has been controversial (Moran 2003), so I have presented the results with and without the correction in Table 1. I also discuss these specific instances in the Results and Discussion sections below.

\section{Results}

The results of the paired samples Student's $t$ tests were mixed. Aggressive responses toward homotypic songs and heterotypic songs were significantly differ- 


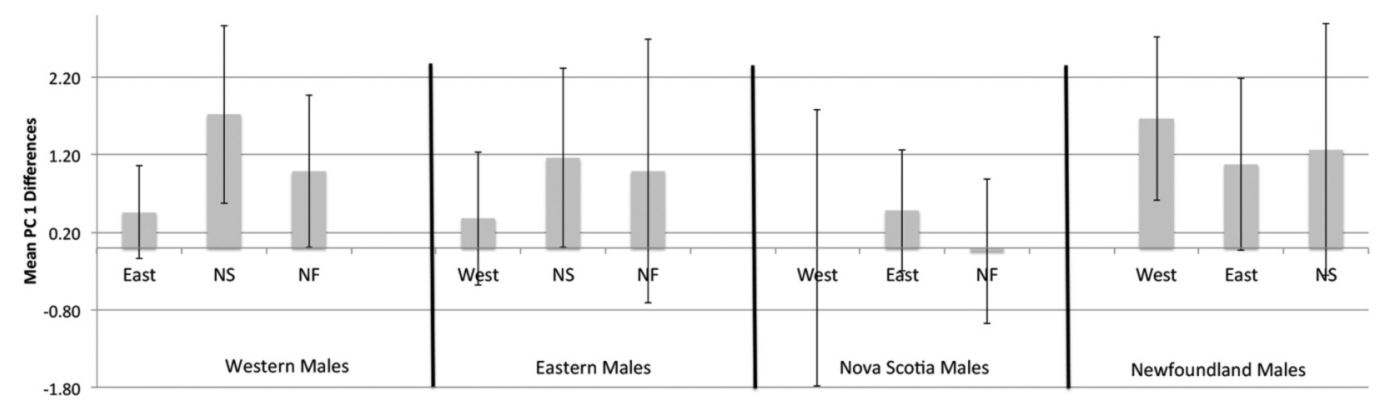

FIGURE 3. Mean differences in first principal component (PC1) scores between responses to homotypic and heterotypic songs by focal male Mourning Warblers (Geothlypis philadelphia) within each regiolect. Error bars are confidence intervals that reflect sequential Bonferroni-corrected alpha values. West $=$ western regiolect, East $=$ eastern regiolect, NS $=$ Nova Scotia regiolect, $\mathrm{NF}=$ Newfoundland regiolect.

ent among males from extreme western and eastern parts of the breeding range. But interior populations from the eastern and Nova Scotia regiolects showed little or no differences in level of aggression toward homotypic and heterotypic songs (Table 1, Figure 3).

For males singing the western regiolect in the Prairie Provinces, results from Student's $t$ tests suggest complete song discrimination. Western males responded more strongly to homotypic songs compared with heterotypic songs from Nova Scotia $(t=5.79$, two-tailed, $\mathrm{df}=9, P<0.001)$ and Newfoundland $(t=3.87$, twotailed, $\mathrm{df}=9, P=0.004)$ regiolects. The results suggest that western males also responded more aggressively to homotypic songs versus the eastern regiolect, but the comparison was not significant after employing the sequential Bonferroni correction $(t=2.74$, twotailed, $\mathrm{df}=8, P=0.026$ ).

The Student's paired $t$ test results for eastern males (Table 1, Figure 3) supported the partial song discrimination hypothesis. Eastern males responded more aggressively to homotypic songs versus heterotypic songs from Nova Scotia $(t=3.85$, two-tailed, $\mathrm{df}=9, P=$ $0.004)$. But there were no significant differences in responses to homotypic and heterotypic songs from the western $(t=1.26$, two-tailed, $\mathrm{df}=10, P=0.238)$ or Newfoundland $(t=1.99$, two-tailed, $\mathrm{df}=8, P=0.085)$ regiolects.

The results from experiments with Nova Scotia males supported the third hypothesis of no song discrimination (Table 1, Figure 3). There were no signif- icant differences in response to their own songs versus songs from the western $(t=0.004$, two-tailed, $\mathrm{df}=9$, $P=0.997)$, eastern $(t=1.83$, two-tailed, $\mathrm{df}=11, P=$ $0.095)$, and Newfoundland $(t=-0.11$, two-tailed, $\mathrm{df}=$ $9, P=0.913$ ) regiolects.

In contrast, the results for Newfoundland males suggested complete discrimination (Table 1, Figure 3), similar to that found in western males. The differences in responses by Newfoundland males toward homotypic songs compared with heterotypic songs from the western $(t=5.85$, two-tailed, $\mathrm{df}=9, P<0.001)$ and eastern $(t=3.93$, two-tailed, $\mathrm{df}=9, P=0.003)$ regiolects were significant. In both cases, males responded more aggressively toward homotypic songs. Although there also was a difference between responses to homotypic versus Nova Scotia regiolects by these males $(t$ $=2.70$, two-tailed, $\mathrm{df}=9, P=0.024)$, it was not significant after the sequential Bonferroni correction.

\section{Discussion}

These results for song discrimination by the Mourning Warbler are in general agreement with previous studies of song playback experiments in other species where males exhibited higher levels of aggression toward local, homotypic songs than heterotypic songs from distant parts of the breeding range (Regelski and Moldenhauer 1996; Searcy et al. 1997; Dufty and Hanson 1999; Nelson and Soha 2004; Price 2008). However, not all populations discriminated between homotypic and heterotypic songs (Table 2). Mourning

TABLE 2. Ability of focal males to discriminate among songs of other Mourning Warblers (Geothlypis philadelphia) from four regiolects within the species' breeding range. No discrimination = no significant difference in responses to homotypic and heterotypic songs; Discrimination = significant difference in responses to homotypic and heterotypic songs; Equivocal $=P<0.05$ based on Student's $t$ tests, but not significant after sequential Bonferroni correction.

\begin{tabular}{lllll}
\hline \hline Regiolect of focal male & \multicolumn{4}{l}{ Response to regiolect of playback song } \\
\cline { 2 - 5 } & Western & Eastern & Nova Scotia & Newfoundland \\
\hline Western & - & Equivocal & Discrimination & Discrimination \\
Eastern & No discrimination & - & Discrimination & No discrimination \\
Nova Scotia & No discrimination & No discrimination & - & No discrimination \\
Newfoundland & Discrimination & Discrimination & Equivocal & - \\
\hline \hline
\end{tabular}


Warbler males at the extremes of the breeding range showed the highest levels of discrimination by responding more aggressively to homotypic than heterotypic songs. Males from the western and Newfoundland regiolects could discriminate between their own songs and at least two of the other regiolects. They may also recognize differences for the remaining regiolects but the Student's $t$ test results were not significant after the sequential Bonferroni correction. These findings support the hypothesis of complete discrimination by populations at the extreme eastern and western parts of the breeding range.

Song discrimination by interior populations of the eastern regiolect was weaker and supported the partial discrimination hypothesis. Eastern males discriminated between eastern songs and the Nova Scotia regiolect. However, they did not discriminate behaviourally between homotypic songs and the neighbouring Western regiolect or between homotypic songs and the Newfoundland regiolect. The results for the Nova Scotia experiments supported the complete lack of discrimination hypothesis. These males showed equal levels of aggression toward homotypic and heterotypic songs when challenged with songs from all of the other regiolects.

One explanation for the spatial pattern of discrimination by Mourning Warbler males is a combination of the effects of geographic proximity and song learning. Repeated exposure and song learning have been shown to modify song recognition among and within species (Irwin and Price 1999; MacDougall-Shackleton et al. 2001; Price 2008). If geographic proximity and experience influence song discrimination in Mourning Warblers, then we should observe two different results from these playback experiments. Allopatric populations separated by large distances should exhibit song discrimination because there is no contact or opportunity to learn each other's songs. In contrast, sympatric populations should show little or no discrimination because of geographic proximity and previous experience with different song types that they may later recognize as equally potent threats to territorial ownership.

Males from the western and Newfoundland populations were mutually capable of song discrimination between their regiolects. Results for these allopatric populations support the idea that a lack of contact and experience with songs leads to song discrimination. The inconsistent patterns of discrimination by populations from the interior of the breeding range appear to support the contention that populations in close proximity may not discriminate among different songs. For instance, eastern males did not recognize differences in western songs and these populations overlap in a large admixture zone in the western Great Lakes region. However, the role of geographic proximity is still unclear for these interior populations.
The playback experiments within the western and eastern regiolects were outside the admixture zone (Figure 1), so it is unclear why males from New Hampshire and Maine could recognize the western regiolect as a threat equal to eastern songs from other locations. Another problem arises from results where allopatric populations were not able to discriminate between homotypic and heterotypic songs. Eastern and Newfoundland populations are separated by the Gulf of St. Lawrence but eastern males responded equally to both song types. Nova Scotia and western populations are also allopatric, but Nova Scotia males reacted strongly to western songs. An alternative explanation for some of these inconsistencies in song discrimination is that the divergence among song types from the eastern and Nova Scotia regiolects is too recent and does not exceed the limits of recognition by these males. Although Pitocchelli (2011b) found statistical differences in syllables and physical parameters of these songs, males still recognize them as a threat to territorial ownership.

Playback experiments that show song discrimination among different populations have been cited as evidence of reproductive isolation (Balakrishnan and Sorenson 2006; Danner et al. 2011). Irwin and colleague's (2001) study of mitochondrial DNA differences among populations of Old World Leaf Warblers (Phylloscopus spp.) confirmed reproductive isolation that paralleled evidence from playback experiments. Studies of mitochondrial DNA and playback experiments on Chiffchaff superspecies (Phylloscopus) produced similar results (Helbig et al. 1996; Martens 1996). If song discrimination by Mourning Warblers also indicates prezygotic isolation, then populations from the Prairie Provinces may be reproductively isolated from allopatric populations in Nova Scotia and Newfoundland. Newfoundland populations may also be reproductively isolated from continental populations based on successful discrimination of their songs from songs of the western and eastern regiolects.

Although these results suggest prezygotic isolation between some populations, additional playback experiments with females (if possible) would be informative. Relying on male responses alone may not always indicate isolation between different song populations. Danner et al. (2011) found gender differences in Rufous-collared Sparrow's (Zonotrichia capensis) responses to homotypic and heterotypic songs. Males did not differ in their responses to homotypic or heterotypic dialects, while females reacted more strongly to the local, homotypic songs. The pattern of female responses to different dialects was correlated with genetic differences between populations while male responses were not. Relying on evidence from male responses alone would not have revealed this divergence. Analyses of mitochondrial DNA and nuclear DNA from Mourning Warblers in each regiolect would ultimately be necessary to clarify actual levels of pop- 
ulation divergence and whether genetic divergence is correlated with song differences in this species.

\section{Acknowledgements}

This work was funded in large part by a summer research grant from Saint Anselm College. I thank the staff at the Geisel Library, especially Jeff Waller, Sue Gagnon, and Sam Urtz, for their help with procuring books and journal titles through inter-library loan. The manuscript benefited from insightful comments provided by Darren Irwin, Robert Rockwell, and two anonymous reviewers. I also thank Joe Troisi, Kathy Flannery, and Lori LaPlante for discussions and suggestions regarding experimental design and appropriate statistical analyses.

\section{Literature Cited}

Anderson, R. C. 2009. Operant conditioning and copulation solicitation display assays reveal a stable preference for local song by female swamp sparrows Melospiza georgiana. Behavioral Ecology and Sociobiology 64: 215-223.

Baker, M. C., D. B. Thompson, G. L. Sherman, and M. A. Cunningham. 1981. The role of male vs female interactions in maintaining population dialect structure. Behavioral Ecology and Sociobiology 8: 65-69.

Balaban, E. 1988. Cultural and genetic variation in Swamp Sparrows (Melospiza Georgiana). II Behavioral salience of geographic song variants. Behaviour 105: 292-322.

Balakrishnan, C. N., and M. D. Sorenson. 2006. Song discrimination suggests premating isolation among sympatric indigobird species and host races. Behavioral Ecology 17: 473-478.

Danner, J. E., R. M. Danner, F. Bonier, P. R. Martin, T. W. Small, and I. T. Moore. 2011. Female, but not male, tropical sparrows respond more strongly to local song dialect: implications for population divergence. American Naturalist 178: 53-63.

Dufty, Jr., A. M., and A. Hanson. 1999. Vocal and behavioral responses of Brown-headed Cowbirds to flight whistles from different dialects. The Condor 101: 484-492.

Edwards, S. V., S. B. Kingan, J. D. Calkins, C. N. Balakrishnan, W. B. Jennings, W. J. Swanson, and M. D. Sorenson. 2005. Speciation in birds: genes, geography, and sexual selection. Proceedings of the National Academy of Sciences USA 102 (Suppl. 1): 6550-6557.

Fleischer, R. C., and S. I. Rothstein. 1988. Known secondary contact and rapid gene flow among subspecies and dialects in the Brown-headed Cowbird. Evolution 42: 1146-1158.

Hall, B. K., and B. Hallgrimsson. 2008. Strickberger's Evolution. Fourth edition. Jones and Bartlett Publishers, Sudbury, Massachusetts, USA.

Helbig, A. J., J. Martens, I. Seibold, F. Henning, B. Schottler, and M. Wink. 1996. Phylogeny and species limits in the Palearctic Chiffchaff Phylloscopus collybita complex: mitochondrial genetic differentiation and bioacoustic evidence. Ibis, 138: 650-666

Irwin, D. E., P. Alström, U. Olsson, and Z. M. BrenowitzFredericks. 2001. Cryptic species in the genus Phylloscopus (Old World leaf warblers). Ibis 143: 233-247.

Irwin, D. E., and T. Price. 1999. Sexual imprinting, learning and speciation. Heredity 82: 347-354.

Kroodsma, D. E. 1989 Suggested experimental designs for song playbacks. Animal Behaviour 37: 600-609.
Kroodsma, D., B. E. Byers, E. Goodale, S. Johnson, and W. C. Liu. 2001. Pseudoreplication in playback experiments, revisited a decade later. Animal Behaviour 61: 1029-1033.

Lanyon, W. E. 1978. Revision of the Myiarchus flycatchers of South America. Bulletin of the American Museum of Natural History 161: 427-628.

Liu, I. A., B. Lohr, B. Olsen, and R. Greenber. 2008. Macrogeographic vocal variation in subspecies of Swamp Sparrow. The Condor 110: 102-109.

MacDougall-Shackleton, S. A., E. A. MacDougall-Shackleton, and T. P. Hahn. 2001. Physiological and behavioural responses of female Mountain White-crowned Sparrows to natal- and foreign-dialect songs. Canadian Journal of Zoology. 79: 325-333.

Martens, J. 1996. Vocalizations and speciation of Palearctic birds. Pages. 221-240 in Ecology and Evolution of Acoustic Communication in Birds. Edited by D. E. Kroodsma, and E. H. Miller. Cornell University Press, Ithaca, New York, USA.

Martin P. R., and T. E. Martin. 2001. Behavioral interactions between coexisting species: song playback experiments with wood warblers. Ecology 82: 207-218.

Mayr, E., and L. L. Short. 1970. Species taxa of North American birds, a contribution to comparative systematics. Publications of the Nuttall Ornithological Club. 9.

McGregor, P. K., and T. Dabelsteen. 1996. Communication networks. Pages 409-425 in Ecology and Evolution of Acoustic Communication in Birds. Edited by D. E. Kroodsma, and E. H. Miller. Cornell University Press, Ithaca, New York, USA.

Moran, M. D. 2003. Arguments for rejecting the sequential Bonferroni in ecological studies. Oikos 100: 403-405.

Mundinger, P. C. 1982. Microgeographic and macrogeographic variation in the acquired vocalizations of birds. Pages 147-208 in Acoustic Communication in Birds. Edited by D. E. Kroodsma and E. H. Miller. Academic Press, New York, New York, USA.

Nelson, D. A., and J. A. Soha. 2004. Perception of geographical variation in song by male Puget White-crowned Sparrows, Zonotrichia leucophrys pugetensis. Animal Behaviour 68: 395-405.

Paterson, H. E. H. 1985. The recognition concept of species. Pages 21-29 in Species and Speciation, Monograph 4 Edited by E. S. Vrba. Transvaal Museum, Pretoria, South Africa.

Pitocchelli, J. 1988. Character variation in the Oporornis philadelphia-tolmiei complex. Ph.D. thesis. Department of Biology, City University of New York, New York, USA.

Pitocchelli, J. 1990. Plumage, morphometric and song variation in Mourning (Oporornis philadelphia) and MacGillivray's (O. tolmiei) warblers. The Auk, 107: 161-171.

Pitocchelli, J. 2011a. Mourning Warbler (Geothlypis philadelphia). In The Birds of North America Online. Edited by A. Poole. Cornell Lab of Ornithology, Ithaca, New York, USA.

Pitocchelli, J. 2011b. Macrogeographic variation in the song of the Mourning Warbler (Oporornis philadelphia). Canadian Journal of Zoology 89: 1027-1040.

Podos, J., and P. S. Warren. 2007. The evolution of geographic variation in birdsong. Advances in the Study of Behavior 37: 403-458.

Price, T. 2008. Speciation in Birds. Roberts and Company, Greenwood Village, Colorado, USA. 
Regelski, D. J., and R. R. Moldenhauer. 1996. Discrimination between regional song forms in the Northern Parula. Wilson Bulletin 108: 335-341.

Remsen, Jr., J. V. 2005. Pattern, process and rigor meet classification. The Auk 122: 403-413.

Rice, W. R. 1989. Analyzing tables of statistical tests. Evolution 43: 223-225.

Searcy, W. A. 1992. Measuring responses of female birds to male song. Pages 175-189 in Playback and Studies of Animal Communication. Edited by P. K. McGregor. Plenum Press, New York, New York, USA.

Searcy, W. A., S. Nowicki, and M. Hughes. 1997. The response of male and female Song Sparrows to geographic variation in song. The Condor 99: 651-657.
Searcy, W. A., S. Nowicki, M. Hughes, and S. Peters. 2002. Geographic song discrimination in relation to dispersal distances in Song Sparrows. American Naturalist 159: 221230.

Soha J, A., D. A. Nelson, and P. G. Parker. 2004. Genetic analysis of song dialect populations in Puget Sound whitecrowned sparrows. Behavioral Ecology 15: 636-646.

Wright T. F., and G. S. Wilkinson. 2001. Population genetic structure and vocal dialects in an Amazon Parrot. Proceedings of the Royal Society of London B 268: 609-616.

Zar, J. H. 2010. Biostatistical Analysis. Fifth edition. Pearson Education, Inc., Upper Saddle River, New Jersey, USA.

Received 8 May 2014

Accepted 20 July 2014 